Check for updates

Cite this: RSC Adv., 2018, 8, 2404

\title{
Terminal aspartic acids promote the self-assembly of collagen mimic peptides into nanospheres $\uparrow$
}

\author{
Linyan Yao, ${ }^{a}$ Manman $\mathrm{He}^{a}{ }^{a}$ Dongfang Li, ${ }^{\mathrm{a}} \mathrm{Jing} \mathrm{Tian}^{\mathrm{a}}{ }^{\mathrm{H}}$ Huanxiang Liu (D) ${ }^{\mathrm{b}}$ \\ and Jianxi Xiao (D) *a
}

The development of novel strategies to construct collagen mimetic peptides capable of self-assembling into higher-order structures plays a critical role in the discovery of functional biomaterials. We herein report the construction of a novel type of amphiphile-like peptide conjugating the repetitive triple helical $(\mathrm{GPO})_{m}$ sequences characteristic of collagen with terminal hydrophilic aspartic acids. The amphiphilelike collagen mimic peptides containing a variable length of (Gly-Pro-Hyp) $m$ sequences consistently generate well-ordered nanospherical supramolecular structures. The C-terminal aspartic acids have been revealed to play a determinant role in the appropriate self-assembly of amphiphile-like collagen mimic peptides. Their presence is a prerequisite for self-assembly, and their lengths could modulate the morphology of final assemblies. We have demonstrated for the first time that amphiphile-like collagen mimic peptides with terminal aspartic acids may provide a general and convenient strategy to create well-defined nanostructures in addition to amphiphile-like peptides utilizing $\beta$-sheet or $\alpha$-helical coiledcoil motifs. The newly developed assembly strategy together with the ubiquitous natural function of collagen may lead to the generation of novel improved biomaterials.

Received 27th October 2017
Accepted 3rd January 2018

DOI: 10.1039/c7ra11855d

rsc.li/rsc-advances as electrostatic interactions, ${ }^{\mathbf{1 2 - 1 4}}$ hydrophobic interactions, ${ }^{\mathbf{1 5 , 1 6}}$ $\pi-\pi$ stacking, ${ }^{17} \pi$-cation interactions, ${ }^{18}$ triple helical nucleation $^{\mathbf{1 9}}$ and metal-ligand interactions ${ }^{\mathbf{2 0 - 2 7}}$ have been harnessed to facilitate the self-assembly of collagen mimic peptides into a wide range of supramolecular structures including fibers, meshes, microflorettes, nanodiscs, and nanosheets. The development of novel strategies to create collagen mimic peptides capable to self-assemble into higherorder structures plays a critical role in the discovery of functional biomaterials.

Amphiphilic peptides have shown fascinating ability to spontaneously aggregate into a large variety of supramolecular self-assembled structures such as nanofibers, nanoribbons, nanotapes, nanotubes and nanovesicles. ${ }^{28-34}$ Peptide amphiphiles (PA) are often designed to mimic surfactant molecules containing a single polar head composed of hydrophilic amino acids and a longer hydrophobic tail consisting of nonpolar amino acids or alkyl chains. ${ }^{33}$ Heteropolymeric peptide amphiphiles containing collagen sequences have been constructed by Fields' and Tirrell's groups, and they have shown enhanced triple helix stability compared to the analogous peptide and they can be applied for surface modification and cell receptor binding. ${ }^{35,36}$ Recently, a peptide amphiphile constructed by conjugating a single hydrophobic alkyl chain with a collagen mimic peptide has been shown to form selfassembled nanofibers. ${ }^{37}$

Amphiphile-like peptides containing a hydrophilic head composed of one or two charged amino acids and 
a hydrophobic tail composed of several consecutive amino acids of increased hydrophobicity have recently been shown to spontaneously self-assemble to form well-ordered nanostructures including micelles, nanovesicles, and nanotubes. ${ }^{30,38,39}$ Peptides $\left(\mathrm{A}_{6} \mathrm{D}, \mathrm{V}_{6} \mathrm{D}, \mathrm{V}_{6} \mathrm{D}_{2}\right.$ and $\left.\mathrm{L}_{6} \mathrm{D}_{2}\right)$ comprising one or two terminal aspartic acids and a tail of hydrophobic amino acids such as alanine, valine, or leucine consistently selfassembled to form nanotubes and nanovesicles. ${ }^{30}$ Peptides $\left(G_{4} D_{2}, G_{6} D_{2}, G_{8} D_{2}\right.$ and $\left.G_{10} D_{2}\right)$ containing variable glycines as the component of the hydrophobic tail and aspartic acids as the hydrophilic head also underwent self-assembly to form ordered nanostructures. ${ }^{39}$ These studies suggested that peptides containing hydrophilic aspartic acids at one terminus and consecutive amino acids of increased hydrophobicity at the other terminus may provide a convenient approach to construct self-assembled nanostructures.

We herein report the design of amphiphile-like collagen mimic peptides consisting of only natural amino acids, which facilitate easy synthesis and high biocompatibility. The peptides contain a single hydrophilic head composed of charged aspartic acids conjugated with the repetitive triple helical (GPO) $)_{m}$ sequences of increased hydrophobicity. We have demonstrated for the first time that these amphiphile-like collagen mimic peptides with terminal aspartic acids may provide a general and convenient strategy to construct welldefined nanostructures.

\section{Experimental section}

\section{Peptide synthesis}

Peptides were synthesized in-house by standard Fmoc solid phase synthesis method. Briefly, the peptides were assembled on 2-chlorotrityl chloride resin (substitution level $=0.88 \mathrm{mmol}$ $\mathrm{g}^{-1}$ resin) at a $0.1 \mathrm{mmol}$ scale. Stepwise couplings of amino acids were accomplished using a double coupling method with Fmoc-amino acids (4 eq.), DIEA (6 eq.) and activator reagents (HBTU + HOBt $0.66 \mathrm{mmol} \mathrm{ml}^{-1}, 4$ eq.). The reaction mixture was washed with DMF $(3 \times 5 \mathrm{ml})$ and DCM $(3 \times 5 \mathrm{ml})$ after each step of coupling, and the Fmoc protection group was removed with $20 \%$ piperidine in DMF. Test reagent ( $2 \%$ ethanol DMF, $2 \%$ chloranil DMF) was used to ensure the successful completion of each coupling reaction and Fmoc deprotection. The peptides were cleaved from the resin and the $t \mathrm{Bu}$ groups were deprotected by treating the resin with TFA/TIS $/ \mathrm{H}_{2} \mathrm{O}$ (95: $2.5: 2.5$ ) for $3 \mathrm{~h}$. The peptides were collected by precipitation with cold $\mathrm{Et}_{2} \mathrm{O}$ and centrifugation. They were resuspended in cold $\mathrm{Et}_{2} \mathrm{O}$, sonicated and centrifuged again. Crude products were then dissolved in water, and lyophilized. The peptides were purified using reverse phase HPLC, and their purity was confirmed by mass spectrometry. $\mathrm{m} / \mathrm{z}$ calculated $2119.3[\mathrm{M}+\mathrm{H}]^{+}$for $(\mathrm{GPO})_{7} \mathrm{D}_{2}$, found $2118.9[\mathrm{M}+\mathrm{H}]^{+} ; \mathrm{m} / \mathrm{z}$ calculated $1584.7[\mathrm{M}+\mathrm{H}]^{+}$for $(\mathrm{GPO})_{5} \mathrm{D}_{2}$, found $1584.69[\mathrm{M}+$ $\mathrm{H}]^{+} ; m / z$ calculated $2653.9[\mathrm{M}+\mathrm{H}]^{+}$for $(\mathrm{GPO})_{9} \mathrm{D}_{2}$, found 2653.2 $[\mathrm{M}+\mathrm{H}]^{+} ; m / z$ calculated $1927.1[\mathrm{M}+\mathrm{K}]^{+}$for $(\mathrm{GPO})_{7}$, found 1926.8 $[\mathrm{M}+\mathrm{K}]^{+} ; m / z$ calculated $2502.6[\mathrm{M}+\mathrm{K}]^{+}$for $(\mathrm{GPO})_{7} \mathrm{D}_{5}$, found $2504.0[\mathrm{M}+\mathrm{K}]^{+}$.

\section{Circular dichroism spectroscopy}

CD spectra were acquired on an Aviv model 400 spectrophotometer (Applied Photophysics Ltd, England) with a Peltier temperature controller. Peptides were prepared at a concentration of $400 \mu \mathrm{M}$ in $10 \mathrm{mM}$ phosphate buffer at $\mathrm{pH} 7.0$ or $200 \mathrm{mM}$ glycine- $\mathrm{HCl}$ buffer at $\mathrm{pH} 3.0$, respectively. The samples were equilibrated for at least $24 \mathrm{~h}$ at $4{ }^{\circ} \mathrm{C}$ prior to the CD measurements. Cells with a path length of $1 \mathrm{~mm}$ were used. Wavelength scans were conducted from 215 to $260 \mathrm{~nm}$ with a $0.5 \mathrm{~nm}$ increment per step and a $0.5 \mathrm{~s}$ averaging time. Thermal unfolding curves were measured by monitoring the amplitude of the characteristic $\mathrm{CD}$ peak at $225 \mathrm{~nm}$, while the temperature was increased $0.3{ }^{\circ} \mathrm{C} \mathrm{min} \min ^{-1}$ from $4{ }^{\circ} \mathrm{C}$ to $70{ }^{\circ} \mathrm{C}$ with an equilibration time of $2 \mathrm{~min}$ at each temperature. The melting temperature $\left(T_{\mathrm{m}}\right)$ was calculated from the first derivative of the thermal unfolding curves.

\section{Dynamic light scattering}

Dynamic light scattering (DLS) measurements were performed on a BI-200SM system (Brookhaven Instruments, USA) equipped with a $514 \mathrm{~nm}$ laser at a $90^{\circ}$ scattering angle. Solutions of peptide $(\mathrm{GPO})_{7} \mathrm{D}_{2}$ with a concentration of $0.5 \mathrm{mg} \mathrm{ml}^{-1}$ were prepared in $100 \mathrm{mM}$ HEPES buffer $(\mathrm{pH} 7.0)$ at $4{ }^{\circ} \mathrm{C}$. The peptide (GPO) $)_{7} \mathrm{D}_{2}$ solution was heated at $20^{\circ} \mathrm{C}$ for $30 \mathrm{~min}$ to initiate the self-assembly, and then incubated at $4{ }^{\circ} \mathrm{C}$ for $60 \mathrm{~h}$. DLS profiles were recorded for the peptide stored at $4{ }^{\circ} \mathrm{C}$ and that incubated at $4{ }^{\circ} \mathrm{C}$ for $60 \mathrm{~h}$ after the heating for $30 \mathrm{~min}$ at $20^{\circ} \mathrm{C}$.

\section{Transmission electron microscopy}

TEM images were obtained on a JEM-2100 transmission electron microscope (JEOL, Japan). Solutions of peptides (GPO) ${ }_{7} \mathrm{D}_{2}$, $(\mathrm{GPO})_{5} \mathrm{D}_{2},(\mathrm{GPO})_{9} \mathrm{D}_{2},(\mathrm{GPO})_{7}$ and $(\mathrm{GPO})_{7} \mathrm{D}_{5}$ with a concentration of $0.5 \mathrm{mg} \mathrm{ml}^{-1}$ were prepared in $100 \mathrm{mM}$ HEPES buffer, $\mathrm{pH}$ 7.0. The samples of peptide $(\mathrm{GPO})_{7} \mathrm{D}_{2}$ were incubated at $4{ }^{\circ} \mathrm{C}$ for $60 \mathrm{~h}$ after heating at $20{ }^{\circ} \mathrm{C}$ for $30 \mathrm{~min}$. The samples of peptide $(\mathrm{GPO})_{5} \mathrm{D}_{2}$ and $(\mathrm{GPO})_{7} \mathrm{D}_{5}$ were incubated at $4{ }^{\circ} \mathrm{C}$ without preheating. Peptide (GPO) ${ }_{9} \mathrm{D}_{2}$ was heated at $47^{\circ} \mathrm{C}$ for $30 \mathrm{~min}$ and then incubated at $4{ }^{\circ} \mathrm{C}$ for $60 \mathrm{~h}$. Peptide $(\mathrm{GPO})_{7}$ was heated at $28{ }^{\circ} \mathrm{C}$ for $30 \mathrm{~min}$ and incubated at $4{ }^{\circ} \mathrm{C}$ for $60 \mathrm{~h}$. A volume of 10 $\mu \mathrm{l}$ of the peptide solution was deposited on a copper grid coated with carbon film. The copper grid was negatively stained with $2.5 \%$ phosphotungstic acid (PTA). Images were recorded at 200 $\mathrm{kV}$.

\section{Results and discussion}

\section{Design of collagen mimic peptides}

We herein construct amphiphile-like peptides $(\mathrm{GPO})_{m} \mathrm{D}_{n}(m=5$, $7,9 ; n=0,2,5)$ incorporating hydrophilic aspartic acids at one terminus and a relatively hydrophobic tail of repetitive $(\mathrm{GPO})_{m}$ sequences at the other terminus (Fig. 1). The most widely used method to describe the hydrophobicity or hydrophilicity of a compound or peptide is the octanol-water partition coefficient $\log P$. Here, to describe the relative hydrophobicity of two terminals of designed peptides, $A \log P$ was calculated.$^{40} A \log P$ of the amino acids or groups was calculated by summing the 
a

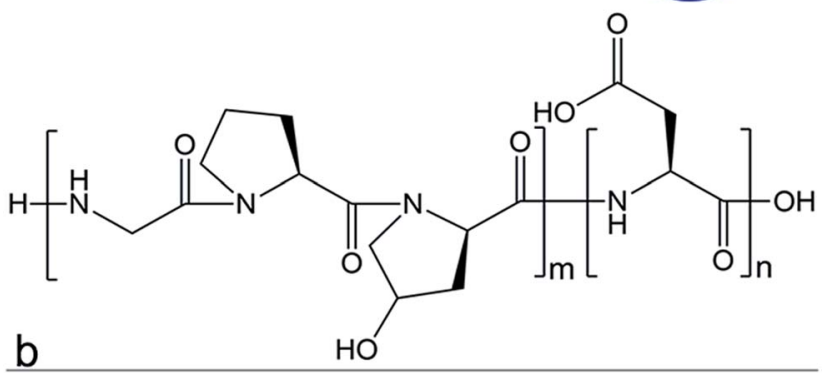

\begin{tabular}{cccc}
\hline Peptide sequence & $\mathbf{m}$ & $\mathbf{n}$ & Melting \\
\hline$(\mathrm{GPO})_{7} \mathrm{DD}$ & 7 & 2 & 25.0 \\
$(\mathrm{GPO})_{5} \mathrm{DD}$ & 5 & 2 & $<4$ \\
$(\mathrm{GPO})_{9} \mathrm{DD}$ & 9 & 2 & 51.8 \\
$(\mathrm{GPO})_{7}$ & 7 & 0 & 33.1 \\
$(\mathrm{GPO})_{7} \mathrm{D}_{5}$ & 7 & 5 & $<4$ \\
\hline
\end{tabular}

Fig. 1 Design and thermal stability of collagen mimic peptides $(\mathrm{GPO})_{m} \mathrm{D}_{n}$. The amphiphile-like peptides consist of hydrophilic aspartic acids $D_{n}(n=0,2,5)$ at $C$-terminus and repetitive triple helical $(\mathrm{GPO})_{m}$ sequences $(m=5,7,9)$ of increased hydrophobicity at $\mathrm{N}$-terminus.

hydrophobic constant of each atom using Discovery Studio (version 2.5.5). The $A \log P$ of amino acids Gly, Pro, Hyp and Asp was $-1.145,-0.116,-1.207$ and -2.753 , respectively. A more negative value of $A \log P$ represented a more hydrophilic amino acid, suggesting that Pro is more hydrophobic than Gly and Hyp, while all these three residues are more hydrophobic than Asp. The $A \log P$ of amino acid groups GPO, GGG and DD was $-2.511,-3.025$ and -5.303 , respectively, suggesting that all the residue groups GPO and GGG were more hydrophobic than DD. These results suggested that our constructed peptides $(\mathrm{GPO})_{m} \mathrm{D}_{2}(m=5,7,9)$ as well as previously reported peptides $\mathrm{G}_{n} \mathrm{D}_{2}(n=4,6,8,10)$ were amphiphile-like.

Three peptides $(\mathrm{GPO})_{7} \mathrm{D}_{2},(\mathrm{GPO})_{5} \mathrm{D}_{2}$, and $(\mathrm{GPO})_{9} \mathrm{D}_{2}$ were constructed to investigate if the lengths of the repetitive GPO triplets affect the self-assembly of the peptides. The GPO triplet is the most abundant amino acid sequence in collagen, and is known to stabilize the triple helix structure. Two more peptides $(\mathrm{GPO})_{7}$ and $(\mathrm{GPO})_{7} \mathrm{D}_{5}$ were constructed to evaluate if the number of aspartic acids modulates the self-assembly of the peptides. All the peptides were composed of only natural amino acids, leading to high biocompatibility and easy synthesis.

\section{Self-assembly of peptide (GPO) $)_{7} \mathrm{DD}$}

To mimic collagen, the constructed peptides should possess the characteristic collagen triple helix structure. The terminal negatively charged amino acids may provide peptide (GPO) 7 DD $\mathrm{pH}$-responsive properties, and its $\mathrm{pI}$ was calculated as 3.6. We therefore characterized the peptide at two pHs: $\mathrm{pH} 7.0$ at which the peptide was negatively charged, and $\mathrm{pH} 3.0$ at which the peptide was almost neutral (Fig. 2a-f). Circular dichroism (CD) spectra of peptide (GPO) ${ }_{7} \mathrm{DD}$ exhibited a characteristic peak at $225 \mathrm{~nm}$ at both $\mathrm{pH} 7.0$ and $\mathrm{pH} 3.0$, indicating the formation of triple helix structure. Thermal unfolding studies showed that peptide (GPO) 7 DD formed a stable triple helix with a melting temperature $\left(T_{\mathrm{m}}\right)$ of $25.0{ }^{\circ} \mathrm{C}$ for $\mathrm{pH} 7.0$ and $29.2{ }^{\circ} \mathrm{C}$ for $\mathrm{pH} 3$, respectively. The $\mathrm{CD}$ results suggested that the peptide could form stable triple helix conformation under a wide range of $\mathrm{pHs}$, while the repulsive electrostatic interactions of the terminal charged aspartic acids finely tuned the thermal stability of the peptide (Fig. 2a-f).

The ability of peptide (GPO) $)_{7} \mathrm{DD}$ to self-assemble was monitored by dynamic light scattering (DLS). Peptide solutions with a concentration of $0.5 \mathrm{mg} \mathrm{ml}{ }^{-1}$ were prepared, and maintained at $4{ }^{\circ} \mathrm{C}$. The peptide solution was heated at $20^{\circ} \mathrm{C}$ for $30 \mathrm{~min}$ to initiate the self-assembly, and incubated at $4{ }^{\circ} \mathrm{C}$ for $60 \mathrm{~h}$. These conditions were optimized, as earlier studies have suggested that the temperature near $T_{\mathrm{m}}$ is a favoured condition for the self-assembly of collagen mimic peptides, since the loosening of the triple helix and the increased mobility of side chains may promote intermolecular interactions leading to supramolecular structures. ${ }^{41}$ The DLS data showed that the peptide stored at $4{ }^{\circ} \mathrm{C}$ (black) displayed a hydrodynamic radius of approximately $2 \mathrm{~nm}$, suggesting no aggregate formation (Fig. S1 $\dagger$ ). The incubation at $4{ }^{\circ} \mathrm{C}$ for $60 \mathrm{~h}$ after preheating at $20^{\circ} \mathrm{C}$ for $30 \mathrm{~min}$ (red) significantly increased the hydrodynamic radius to be $\sim 300 \mathrm{~nm}$, indicating the formation of large assembled particles (Fig. S1†).

The morphology of the assembled materials formed by peptide $(\mathrm{GPO})_{7} \mathrm{DD}$ was characterized by transmission electron microscopy (TEM). Peptide solutions of (GPO) $)_{7} \mathrm{DD}$ with a concentration of $0.5 \mathrm{mg} \mathrm{ml}^{-1}$ were prepared in $100 \mathrm{mM}$
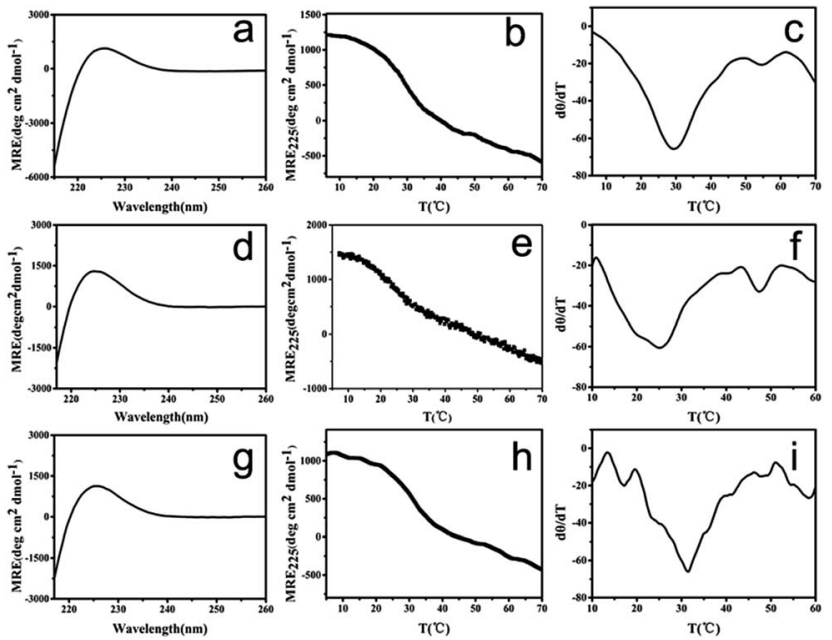

Fig. $2 \mathrm{CD}$ characterization of collagen mimic peptide (GPO) ${ }_{7} \mathrm{DD}$. CD spectra (a), CD thermal unfolding (b) and the first derivative $(d[\theta] / d T)$ of the $C D$ unfolding curve (c) of the unheated peptide at $\mathrm{pH}$ 3.0. $C D$ spectra (d), CD thermal unfolding (e) and the first derivative $(d[\theta] / d T)$ of the $C D$ unfolding curve $(f)$ of the unheated peptide at $\mathrm{pH}$ 7.0. $C D$ spectra (g), CD thermal unfolding (h) and the first derivative $(d[\theta] / d T)$ of the $\mathrm{CD}$ unfolding curve (i) of the preheated peptide at $\mathrm{pH}$ 7.0. 
HEPES buffer, pH 7.0. TEM image of the peptide maintained at $4{ }^{\circ} \mathrm{C}$ without preheating indicated the absence of any assembled supramolecular structures (Fig. 3a). In contrast, TEM images of the peptide incubated at $4{ }^{\circ} \mathrm{C}$ for $60 \mathrm{~h}$ after preheating at $20{ }^{\circ} \mathrm{C}$ for $30 \mathrm{~min}$ resulted in relatively uniformly distributed nanospheres with an average diameter of $\sim 300 \pm 10 \mathrm{~nm}$ (Fig. 3b-c). It suggested that the amphiphile-like collagen mimic peptides may provide an excellent strategy to create well-ordered nanospheres.

The peptide solution incubated at $4{ }^{\circ} \mathrm{C}$ for $60 \mathrm{~h}$ after preheating at $20{ }^{\circ} \mathrm{C}$ for $30 \mathrm{~min}$ was also characterized by $\mathrm{CD}$ (Fig. $2 \mathrm{~g}-\mathrm{i}$ ). The CD spectra exhibited a characteristic peak at $225 \mathrm{~nm}$, indicating that the assembled peptide maintained the triple helix structure. Thermal unfolding studies further demonstrated that the assembled peptide formed a stable triple helix with a melting temperature $\left(T_{\mathrm{m}}\right)$ of $31.0^{\circ} \mathrm{C}$, which was $6{ }^{\circ} \mathrm{C}$ higher than the $T_{\mathrm{m}}$ of the free, un-assembled peptide $\left(25.0^{\circ} \mathrm{C}\right)$. These results indicated that the self-assembly of peptide (GPO) $)_{7} \mathrm{DD}$ into nanospheres stabilized the triple helix structure.

\section{The effect of the (GPO) $)_{m}$ sequences on the self-assembly of collagen mimic peptides}

Peptides (GPO) ${ }_{5} \mathrm{D}_{2}$ and $(\mathrm{GPO})_{9} \mathrm{D}_{2}$ were constructed to evaluate whether the lengths of the GPO triplets affect the self-assembly of the amphiphile-like collagen mimic peptides. Both peptides were prepared at a concentration of $400 \mu \mathrm{M}$ in $10 \mathrm{mM}$ phosphate buffer at $\mathrm{pH}$ 7.0. CD spectra of peptide $(\mathrm{GPO})_{5} \mathrm{D}_{2}$ displayed a distinct peak at $225 \mathrm{~nm}$ at $4{ }^{\circ} \mathrm{C}$, while its thermal unfolding studies indicated a linear decrease of the $\mathrm{CD}_{225} \mathrm{~nm}$ intensity during its melting, suggesting that peptide $(\mathrm{GPO})_{5} \mathrm{D}_{2}$ may contain some triple helical species at $4{ }^{\circ} \mathrm{C}$, but it could not form stable triple helix at higher temperatures (Fig. S2a-c $\dagger$ ). Meanwhile, CD spectra of peptide (GPO) ${ }_{9} \mathrm{D}_{2}$ contained a characteristic peak at $225 \mathrm{~nm}$ at $4{ }^{\circ} \mathrm{C}$, and its thermal unfolding studies indicated that peptide (GPO) ${ }_{9} \mathrm{D}_{2}$ formed a stable triple helix with $T_{\mathrm{m}}$ of $51.8{ }^{\circ} \mathrm{C}$ (Fig. S2d-f $\dagger$ ).

The morphology of the assembled materials formed by both peptides was characterized by transmission electron microscopy (TEM). Peptide solutions with a concentration of $0.5 \mathrm{mg}$ $\mathrm{ml}^{-1}$ were prepared in $100 \mathrm{mM}$ HEPES buffer, $\mathrm{pH}$ 7.0. Peptide (GPO) ${ }_{5} \mathrm{DD}$ was incubated at $4{ }^{\circ} \mathrm{C}$ for $60 \mathrm{~h}$. Peptide(GPO) ${ }_{9} \mathrm{DD}$ was heated at $47^{\circ} \mathrm{C}$ for $30 \mathrm{~min}$ and incubated at $4{ }^{\circ} \mathrm{C}$ for $60 \mathrm{~h}$. The DLS data showed that both peptides displayed a large

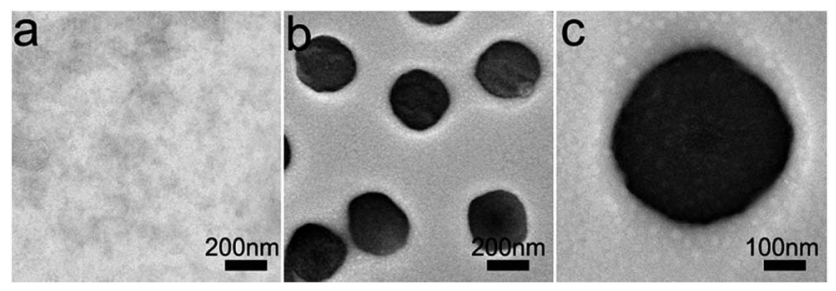

Fig. 3 TEM images of peptide (GPO) $)_{7} D D$ maintained at $4{ }^{\circ} \mathrm{C}(\mathrm{a})$ or incubated at $4{ }^{\circ} \mathrm{C}$ for $60 \mathrm{~h}$ after preheating at $20^{\circ} \mathrm{C}$ for $30 \mathrm{~min}(\mathrm{~b}$ and c). Peptide solutions of (GPO) 7 DD with a concentration of $0.5 \mathrm{mg} \mathrm{ml}^{-1}$ were prepared in $100 \mathrm{mM}$ HEPES buffer, $\mathrm{pH}$ 7.0. hydrodynamic radius after incubation, indicating the formation of assembled particles (Fig. S3†). TEM image of the assemblies of peptide (GPO) ${ }_{5} \mathrm{DD}$ revealed uniformly distributed nanospheres with an average diameter of $\sim 325 \pm 10 \mathrm{~nm}$ (Fig. 4a and b), while TEM image of peptide (GPO) ${ }_{9} \mathrm{DD}$ showed nanospheres with an average diameter of $\sim 270 \pm 10 \mathrm{~nm}$ (Fig. $4 \mathrm{c}$ and d). These results indicated that amphiphile-like collagen mimic peptides $(\mathrm{GPO})_{m} \mathrm{DD}$ with a variable length of GPO triplets $(m=5,7,9)$ all resulted in relatively uniform nanospheres. As the lengths of the triple helix formed by peptides (GPO) $)_{5} \mathrm{DD},(\mathrm{GPO})_{7} \mathrm{DD}$ and $(\mathrm{GPO})_{9} \mathrm{DD}$ were gradually increased, the nanoparticle size of the assemblies became smaller. It implied that smaller collagen mimic peptides may be more flexible and easier to nucleate and aggregate. The lengths of the $(\mathrm{GPO})_{m}$ sequences may not affect the proper self-assembly of the peptides, while they may finely tune the size of the final assembled nanospheres.

\section{The effect of the aspartic acids on the self-assembly of collagen mimic peptides}

Peptides $(\mathrm{GPO})_{7}$ and $(\mathrm{GPO})_{7} \mathrm{D}_{5}$ were designed to examine whether the number of aspartic acids at C-terminal affect the self-assembly of the amphiphile-like collagen mimic peptides. Both peptides with a concentration of $400 \mu \mathrm{M}$ were prepared in $10 \mathrm{mM}$ phosphate buffer, $\mathrm{pH}$ 7.0. CD spectra of peptide (GPO) showed a typical peak at $225 \mathrm{~nm}$ at $4{ }^{\circ} \mathrm{C}$, and its thermal unfolding studies indicated that peptide $(\mathrm{GPO})_{7}$ formed a stable triple helix with $T_{\mathrm{m}}$ of $33.1{ }^{\circ} \mathrm{C}$ (Fig. S4a-c $\dagger$ ). Meanwhile, CD spectra of peptide $(\mathrm{GPO})_{7} \mathrm{D}_{5}$ contained a characteristic peak at $225 \mathrm{~nm}$ at $4{ }^{\circ} \mathrm{C}$, while its thermal unfolding studies showed a linear decrease of the $\mathrm{CD}_{225} \mathrm{~nm}$ intensity, suggesting that peptide $(\mathrm{GPO})_{7} \mathrm{D}_{5}$ may possess some triple helical species at $4{ }^{\circ} \mathrm{C}$, but it could not form stable triple helix at higher temperatures (Fig. S4d-f $\dagger$ ).

Peptide $(\mathrm{GPO})_{7} \mathrm{D}_{5}$ was incubated at $4{ }^{\circ} \mathrm{C}$ for $60 \mathrm{~h}$.

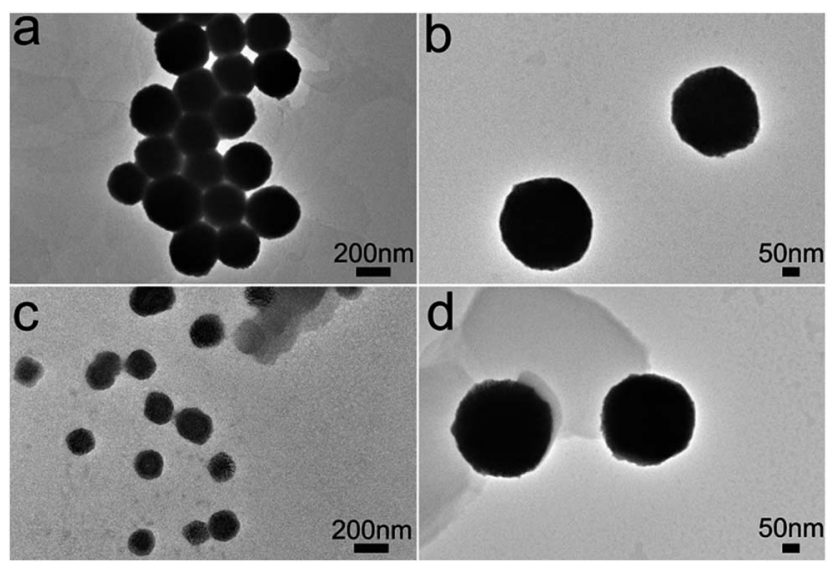

Fig. 4 TEM images of amphiphile-like collagen mimic peptides $(\mathrm{GPO})_{5} \mathrm{DD}(\mathrm{a}$ and $\mathrm{b})$ and $(\mathrm{GPO})_{9} \mathrm{DD}$ (c and d). Peptide solutions with a concentration of $0.5 \mathrm{mg} \mathrm{ml}^{-1}$ were prepared in $100 \mathrm{mM}$ HEPES buffer, $\mathrm{pH}$ 7.0. Peptide (GPO) 5 DD was incubated at $4{ }^{\circ} \mathrm{C}$ for $60 \mathrm{~h}$. Peptide (GPO) ${ }_{9} \mathrm{DD}$ was heated at $47^{\circ} \mathrm{C}$ for $30 \mathrm{~min}$ and incubated at $4{ }^{\circ} \mathrm{C}$ for $60 \mathrm{~h}$. 


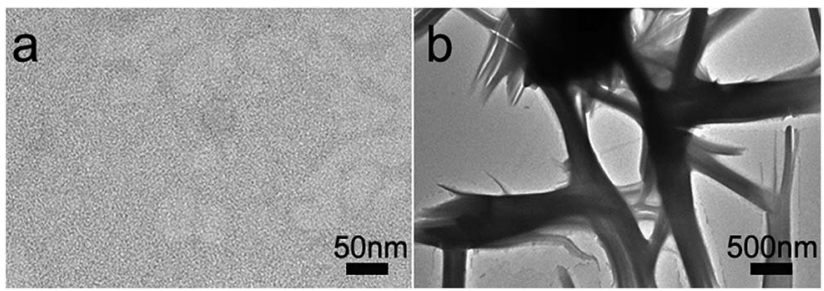

Fig. 5 TEM images of collagen mimic peptides $(\mathrm{GPO})_{7}$ (a) and $(G P O)_{7} D_{5}$ (b). Peptide solutions with a concentration of $0.5 \mathrm{mg} \mathrm{ml}^{-1}$ were prepared in $100 \mathrm{mM} \mathrm{HEPES}$ buffer, $\mathrm{pH}=7.0$. Peptide $(\mathrm{GPO})_{7}$ was heated at $28^{\circ} \mathrm{C}$ for $30 \mathrm{~min}$ and incubated at $4{ }^{\circ} \mathrm{C}$ for $60 \mathrm{~h}$.

The morphology of the assembled materials formed by peptides $(\mathrm{GPO})_{7}$ and $(\mathrm{GPO})_{7} \mathrm{D}_{5}$ were characterized by transmission electron microscopy (TEM). Peptide solutions with a concentration of $0.5 \mathrm{mg} \mathrm{ml}{ }^{-1}$ were prepared in $100 \mathrm{mM}$ HEPES buffer, $\mathrm{pH}$ 7.0. Peptide $(\mathrm{GPO})_{7}$ was heated at $28{ }^{\circ} \mathrm{C}$ for $30 \mathrm{~min}$ and incubated at $4{ }^{\circ} \mathrm{C}$ for $60 \mathrm{~h}$, while peptide $(\mathrm{GPO})_{7} \mathrm{D}_{5}$ was incubated at $4{ }^{\circ} \mathrm{C}$ for $60 \mathrm{~h}$. TEM image of peptide (GPO) 7 did not indicate the presence of any assemblies (Fig. 5a). In contrast, TEM image of peptide $(\mathrm{GPO})_{7} \mathrm{D}_{5}$ revealed the formation of some fibrous assemblies (Fig. 5b). These results indicated that the C-terminal aspartic acids played a determinant role in the proper self-assembly of amphiphile-like collagen mimic peptides. The presence of C-terminal aspartic acids is required to initiate the self-assembly, while a proper number of aspartic acids is needed to modulate the morphology of final assemblies.

\section{Conclusions}

The construction of novel collagen mimetic peptides capable to self-assemble into well-defined supramolecular structures plays an essential role in the discovery of functional biomaterials. Amphiphile-like peptides have attracted extensive attention as molecular building blocks for the fabrication of higher-order structures and they have shown promising applications in the fields of bioengineering and biotechnology ${ }^{42,43}$ A variety of supramolecular structures have been achieved utilizing amphiphile-like peptides composed of $\beta$-sheet or $\alpha$-helical coiled-coil motifs. ${ }^{32,44,45}$

We herein report the construction of amphiphile-like peptides consisting of the repetitive triple helical $(\mathrm{GPO})_{m}$ sequences characteristic of collagen and terminal hydrophilic aspartic acids. The amphiphile-like collagen mimic peptides consisting of (Gly-Pro-Hyp) $)_{m}$ sequences of variable lengths consistently form well-ordered nanospherical supramolecular structures, indicating that the lengths of the $(\mathrm{GPO})_{m}$ sequences may not interfere the proper self-assembly of the peptides, while they could probably finely tune the size of the final assembled nanospheres. In contrast, the C-terminal aspartic acids played a determinant role in the appropriate self-assembly of amphiphile-like collagen mimic peptides, whose presence is a prerequisite for the self-assembly, and whose lengths could modulate the morphology of final assemblies.
We have demonstrated for the first time that amphiphile-like collagen mimic peptides with terminal aspartic acids may provide a general and convenient strategy to create well-defined nanostructures in addition to amphiphile-like peptides composed of $\beta$-sheet or $\alpha$-helical coiled-coil motifs. The collagen mimic peptides are composed of only natural amino acids, which will facilitate easy synthesis as well as superior biocompatibility of the peptides for promising biological applications. The newly developed assembly strategy together with the ubiquitous natural function of collagen may lead to the generation of novel improved biomaterials.

\section{Conflicts of interest}

The authors declare no competing conflict of interests.

\section{Acknowledgements}

This work was supported by grants from the National Natural Science Foundation of China (Grant No. 21775059) and the Fundamental Research Funds for the Central Universities (Grant No. lzujbky-2016-k10).

\section{References}

1 J. A. Fallas, L. E. O'Leary and J. D. Hartgerink, Chem. Soc. Rev., 2010, 39, 3510-3527.

2 M. D. Shoulders and R. T. Raines, Annu. Rev. Biochem., 2009, 78, 929-958.

3 C. M. Kielty and M. E. Grant, in Connective tissue and its heritable disorders, molecular, genetic and medical aspects, ed. P. M. Royes and B. U. Steinmann, Wiley Liss, New York, 2002, pp. 159-222.

4 J. Myllyharju and K. I. Kivirikko, Ann. Med., 2001, 33, 7-21.

5 J. C. Marini, A. Forlino, W. A. Cabral, A. M. Barnes, J. D. San Antonio, S. Milgrom, J. C. Hyland, J. Korkko, D. J. Prockop, A. De Paepe, P. Coucke, S. Symoens, F. H. Glorieux, P. J. Roughley, A. M. Lund, K. Kuurila-Svahn, H. Hartikka, D. H. Cohn, D. Krakow, M. Mottes, U. Schwarze, D. Chen, K. Yang, C. Kuslich, J. Troendle, R. Dalgleish and P. H. Byers, Hum. Mutat., 2007, 28, 209-221.

6 J. Xiao, X. Sun, B. Madhan, B. Brodsky and J. Baum, J. Biol. Chem., 2015, 290, 24201-24209.

7 B. Brodsky and A. V. Persikov, Adv. Protein Chem., 2005, 70, 301-339.

8 J. Xiao and J. Baum, J. Am. Chem. Soc., 2009, 131, 1819418195.

9 B. Brodsky, G. Thiagarajan, B. Madhan and K. Kar, Biopolymers, 2008, 89, 345-353.

10 G. B. Fields, Org. Biomol. Chem., 2010, 8, 1237-1258.

11 Y. Li and S. M. Yu, Curr. Opin. Chem. Biol., 2013, 17, 968-975. 12 L. E. O'Leary, J. A. Fallas, E. L. Bakota, M. K. Kang and J. D. Hartgerink, Nat. Chem., 2011, 3, 821.

13 S. Rele, Y. H. Song, R. P. Apkarian, Z. Qu, V. P. Conticello and E. L. Chaikof, J. Am. Chem. Soc., 2007, 129, 14780. 
14 T. Jiang, C. Xu, Y. Liu, Z. Liu, J. S. Wall, X. Zuo, T. Lian, K. Salaita, C. Ni, D. Pochan and V. P. Conticello, J. Am. Chem. Soc., 2014, 136, 4300-4308.

15 M. A. Cejas, W. A. Kinney, C. Chen, J. G. Vinter, H. R. Almond Jr, K. M. Balss, C. A. Maryanoff, U. Schmidt, M. Breslav, A. Mahan, E. Lacy and B. E. Maryanoff, Proc. Natl. Acad. Sci. U. S. A., 2008, 105, 8513-8518.

16 K. McGuinness, I. J. Khan and V. Nanda, ACS Nano, 2014, 8, 12514-12523.

17 M. A. Cejas, W. A. Kinney, C. Chen, G. C. Leo, B. A. Tounge, J. G. Vinter, P. P. Joshi and B. E. Maryanoff, J. Am. Chem. Soc., 2007, 129, 2202-2203.

18 C. C. Chen, W. Hsu, T. C. Kao and J. C. Horng, Biochemistry, 2011, 50, 2381-2383.

19 B. Sarkar, L. E. O'Leary and J. D. Hartgerink, J. Am. Chem. Soc., 2014, 136, 14417-14424.

20 D. E. Przybyla, C. M. Rubert Perez, J. Gleaton, V. Nandwana and J. Chmielewski, J. Am. Chem. Soc., 2013, 135, 3418-3422.

21 M. M. Pires, D. E. Przybyla, C. M. Rubert Perez and J. Chmielewski, J. Am. Chem. Soc., 2011, 133, 14469-14471.

22 D. E. Przybyla and J. Chmielewski, J. Am. Chem. Soc., 2010, 132, 7866-7867.

23 M. M. Pires and J. Chmielewski, J. Am. Chem. Soc., 2009, 131, 2706-2712.

24 D. E. Przybyla and J. Chmielewski, J. Am. Chem. Soc., 2008, 130, 12610-12611.

25 M. M. Pires, D. E. Przybyla and J. Chmielewski, Angew. Chem., 2009, 48, 7813-7817.

26 M. He, L. Wang, J. Wu and J. Xiao, Chemistry, 2016, 22, 19141917.

27 M. M. Pires, J. Lee, D. Ernenwein and J. Chmielewski, Langmuir, 2012, 28, 1993-1997.

28 S. Fleming and R. V. Ulijn, Chem. Soc. Rev., 2014, 43, 81508177.
29 J. D. Hartgerink, E. Beniash and S. I. Stupp, Science, 2001, 294, 1684-1688.

30 S. Vauthey, S. Santoso, H. Gong, N. Watson and S. Zhang, Proc. Natl. Acad. Sci. U. S. A., 2002, 99, 5355-5360.

31 H. Cui, M. J. Webber and S. I. Stupp, Biopolymers, 2010, 94, 1-18.

32 A. Dehsorkhi, V. Castelletto and I. W. Hamley, J. Pept. Sci., 2014, 20, 453-467.

33 S. Cavalli, F. Albericio and A. Kros, Chem. Soc. Rev., 2010, 39, 241-263.

34 S. E. Paramonov, H. W. Jun and J. D. Hartgerink, J. Am. Chem. Soc., 2006, 128, 7291-7298.

35 Y. C. Yu, V. Roontga, V. A. Daragan, K. H. Mayo, M. Tirrell and G. B. Fields, Biochemistry, 1999, 38, 1659-1668.

36 G. B. Fields, J. L. Lauer, Y. Dori, P. Forns, Y. C. Yu and M. Tirrell, Biopolymers, 1998, 47, 143-151.

37 J. N. Luo and Y. W. Tong, ACS Nano, 2011, 5, 7739-7747.

38 S. Zhang, Acc. Chem. Res., 2012, 45, 2142-2150.

39 S. Santoso, W. Hwang, H. Hartman and S. Zhang, Nano Lett., 2002, 2, 687-691.

40 R. Todeschini and V. Consonni, Handbook of molecular descriptors: Methods and principles in medicinal chemistry, WILEY-VCH Verlag GmbH, 2000.

41 K. Kar, P. Amin, M. A. Bryan, A. V. Persikov, A. Mohs, Y. H. Wang and B. Brodsky, J. Biol. Chem., 2006, 281, 33283-33290.

42 S. Zhang, Nat. Biotechnol., 2003, 21, 1171-1178.

43 E. R. da Silva, W. A. Alves, V. Castelletto, M. Reza, J. Ruokolainen, R. Hussain and I. W. Hamley, Chem. Commun., 2015, 51, 11634-11637.

44 A. Aggeli, I. A. Nyrkova, M. Bell, R. Harding, L. Carrick, T. C. McLeish, A. N. Semenov and N. Boden, Proc. Natl. Acad. Sci. U. S. A., 2001, 98, 11857-11862.

45 D. Papapostolou, E. H. Bromley, C. Bano and D. N. Woolfson, J. Am. Chem. Soc., 2008, 130, 5124-5130. 